\title{
Discussion on Application of Multimedia Teaching in College English Vocabulary Teaching
}

\author{
Xiaoxi Wang \\ School of Applied Technology, The University of Science and Technology Liaoning, Anshan, China \\ Email: XXWang@163.com
}

Received 1 May 2016; accepted 3 June 2016; published 6 June 2016

Copyright (C) 2016 by author and Scientific Research Publishing Inc.

This work is licensed under the Creative Commons Attribution International License (CC BY).

http://creativecommons.org/licenses/by/4.0/

c) (i) Open Access

\begin{abstract}
The rapid development of science and technology has created new condition for the teaching methods of higher English education, which has greatly enriched the English teaching resources and has promoted the renovation of English teaching methods. As a second to none common language in the world, English has always been playing an important role in international communication, and has been valued highly in the educational circles. Compared with previous English teaching, modern college English teaching has the characteristics of convenient and efficient and is easily to be accepted by students. Considering the diversity and comprehensiveness of college English, it is necessary to divide it into such secondary subjects as vocabulary, grammar and reading, in order to help students to develop learning interest in English in daily life, and to achieve the purpose of reducing students' burden. This paper discusses the current application situation and problems of multimedia teaching in college English vocabulary teaching and the countermeasures with emphasis, hoping to provide beneficial views for the research and practice of innovative classroom teaching methods.
\end{abstract}

\section{Keywords}

Multimedia, Teaching Method, College English, English Vocabulary, Classroom Teaching

\section{Introduction}

The introduction of multimedia into teaching has created a new world for English teaching. Multimedia technology is intuitive, vivid, convenient, fast and practical, integrating various information transmission functions, such as sound, image, animation and text, which has improved students' learning efficiency, and is popular 
among teachers. But teaching media is just a kind of teaching tool and instrument, which can't replace the communication between teachers and students, neither can replace teachers' influences on students. Reasonable use of multimedia teaching means will add colors to English teaching, providing vast space for the discussion of teaching method, and the favorable conditions for cultivating students' English abilities.

\section{Current Situation of the Application of Multimedia Teaching in College English Vocabulary Teaching}

In traditional English teaching mode, college English teachers generally concentrate on the explanation of English grammar in classroom. As for the vocabulary, they often ask students to recite the glossary or encourage them to accumulate according to the outline of CET-4 and CET-6. Most of the college teachers have ignored to teach students the scientific memory methods or help students to strengthen their learning ability of vocabulary using correct teaching methods. The majority of students just memorize the words mechanically according to the word order, and they cannot generate effective association when they encounter the words with same roots or of the same nature, which has greatly limited the ways to improve students' English ability, thus it will discourage students' enthusiasm in learning English (Fang, 2006). On the other hand, the college students tend to break away the language environment of native English when they learn the English vocabulary, and ignore the impact on English vocabulary by environmental culture, which will result in "joke" in the actual scene when using English words to make barriers appear in the normal conversation, which has greatly influenced students' enthusiasm in using English.

Therefore, the richness of classroom content and diversity of teaching methods shall be added based on the fact that college English vocabulary teaching can really help students to memorize the use the English vocabulary. On this point, the present college English teachers gradually reached a consensus, as they generally believed that multimedia teaching can play a good supporting role in college English vocabulary teaching, and they have made the practice on this method for a long time, and based on the continuous practice, they have made constant modification on the unreasonable parts, which has formed a unique college English vocabulary teaching method gradually.

\section{Problems of Applying Multimedia Teaching in College English Vocabulary Teaching}

As colleges and universities has made more efforts to English vocabulary teaching in recent years, the schools are facing the pressure and challenges from all walks of life under the background of new teaching reform and society development. These existing pressure and challenge is a "double-edged sword" in the true sense, which will not only make the educational circles realize their deficiencies, so as to supervise and urge itself to positively conduct the educational reform; on the other hand, it will also make students reflect on their previous learning methods, encourage them to correct their own shortcomings through communication with teachers. Therefore, we can explore the problems faced by the application of multimedia teaching in college English vocabulary teaching from the following aspects:

\subsection{Insufficient Multimedia Equipment Investment and Inappropriate Course Setting}

At present, although a lot of colleges and universities have begun to pay more attention to the application of multimedia teaching in college English vocabulary teaching, there are still some colleges and universities cannot realize that the multimedia teaching method is scientific and effective. In such a context, some colleges may have defects in the investment in multimedia teaching equipment resources, resulting in college English teachers can't apply multimedia teaching in college English vocabulary teaching very well. On the other hand, the problems in course setting in some colleges and universities will directly affect the teachers' decision on whether or not apply multimedia teaching in the actual teaching activities (Ji, 2002). For example, in the public course setting of college English in some colleges and universities, the actual teaching hours tend to be reduced for the specialties of science and engineering properties. These students with weak English foundation, however, will lose their interest in English, providing an excuse for their lazy psychology. Under such situation, the college English teachers will abandon the new teaching method and turn to the traditional "words reciting" in order to guarantee the smooth completion of daily teaching tasks, considering the multimedia teaching method is relatively 
time consuming. However, the rejection of teaching methods innovation is the "main cause” of students' unable to use classroom time effectively.

\subsection{Teachers' Quality Needs to Be Improved}

It is undeniable that there are still a lot of teachers can't realize the importance of vocabulary learning in college English teaching, and they have certain resistance to the use of multimedia technology. Although some college English teachers have begun to study the characteristics of English vocabulary teaching that can be easily accepted by students, and edit and integrate them, there is still lack of a kind of effective teaching method as the carrier of these innovative concepts in the actual teaching process. Therefore, on the one hand, college English teachers need to constantly improve their own understanding to flexibly and effectively use various multimedia channels, such as audio, video, images and other forms, to ensure the effective college English vocabulary teaching, and the evaluation and test in the future.

\subsection{Students' Learning Method Needs to Be Improved}

Because of the large number of students of college public English course and the characteristics of "extensive teaching content, short time and heavy task", the use of multimedia to English vocabulary teaching can significantly improve the classroom teaching effect, and help students to broaden the knowledge of English vocabulary. However, such teaching method, on the one hand, will lead to students' unable to distinguish difficult points of teaching, and take down the multimedia teaching content "entirely". On the other hand, some students may haven't developed good study habits and are busy with taking down the contents that teachers have shown on the PPT. The two cases will lead to insufficient communication between students and teachers in the classroom, and over time, students will slowly get used to "taking notes", and ignore the training of their own critical thinking skills in classroom.

\section{Countermeasures of Multimedia Teaching's Application in College English Vocabulary Teaching}

According to the above analysis, it is not hard to find that the problems of multimedia teaching in college English vocabulary teaching are not caused by single reason, but by the common effect of many reasons (Liang, 2000). Therefore, in view of the above questions, the existing problems can be modified in combination with the previous experience analysis from the following aspects:

\subsection{Teachers Shall Pay More Attention to the Multimedia Teaching in College English Vocabulary Teaching to Strive to Improve Their Quality}

Teachers act as the "helmsman" in the application of multimedia teaching in college English vocabulary teaching. Therefore, the role of college English teachers is not only the pusher of teaching method reform, but also the actual planners and commanders ( $\mathrm{Li}$, 2008). This requires teachers to improve their comprehensive quality, and they shall not only pay attention to the selection and arrangement of teaching content, but also shall improve their scientific and technological accomplishments, to make full use of the Internet and multimedia equipment to facilitate their teaching in classroom.

For example, college English teachers can participate in computer technology class for advanced studies in their spare time to conduct targeted modification of their technology. Again, teachers can also take part in some academic seminars and exchange activities actively, to exchange teaching experience with peer teachers, so as to achieve the purpose of improving their achievements.

As for the specific teaching method, teachers can provide a special English vocabulary lecture regarding a certain topic. In teaching of this kind of words, they can be expanded from the aspects of synonyms, antonyms, relevant phrases, roots and affixes etc. Some familiar film and television works and books can be selected to enrich the usage scenarios of the words, in order to strengthen students' understanding and memory.

\subsection{School Shall Actively Cooperate with the Teachers for Teaching Method Reform}

As the supporter college teaching reform, colleges and universities can support the college English teachers to apply multimedia teaching to college English vocabulary teaching from many aspects in the usual teaching 
activity. First of all, colleges and universities can start from the college English course setting, to improve the proportion of college English in various specialties with emphasis, in order to arouse the attention of related teachers and students. Secondly, colleges and universities should contribute to purchase multimedia equipment and build multimedia Internet platform, so as to realize the diversification development of teaching. Again, colleges and universities can organize teachers for English majors for the systematic multimedia technology training, and held seminar and interschool visit and learning from time to time, to realize the comprehensive development of college English teachers (Luo, 2002).

For example, in view of teachers' problems in make the representative multimedia Microsoft Power Point, the promotion activity of "Teachers' PPT Practical Experience" hold by our college not long ago seems very necessary. This activity mainly starts from college teachers' usual practical skills, and with the guidance of professional computer teachers, they are familiar with the whole process of PPT production and beautification quickly. In addition, after this activity, relevant answering channels are established, to facilitate teachers to query the problems of multimedia teaching they care about. Again, colleges and universities also can actively contact social enterprises to carry out joint development, looking for technical support and equipment support. Colleges and universities can sign a talent transfer agreement with the companies that support teaching reform, put forward "orientation training plan", to achieve the professional training of talents.

\subsection{To Teach Using Various Multimedia Tools}

The preciousness of multimedia teaching lies in it conveys the teaching contents to students with the appropriate form after integrating various forms of media. No matter video, audio or picture and mind map, each of them looks like existing alone, but actually they are interdependent and support each other. Further, the multimedia teaching mode is an integration of the existing media, if it can be used flexibly in the actual teaching activities, the efficiency of classroom teaching will be improved significantly.

In the teaching of English vocabulary, "listening, speaking, reading and writing" are also the main approaches for college English vocabulary accumulation. According to the four aspects, college English teachers can add audio and video selectively to the classroom in usual teaching activity, especially in English practice classes. Considering most college students have become the adults with stable mental, teachers need to pay attention to the "conception forming" while selecting the multimedia content, that is to say, the selected material need to conform to the standards for the construction of socialist spiritual civilization. When choosing materials, on the other hand, teachers must take student's interest and actual needs into full consideration, and use some American TV series or Disney animated films that students watch at ordinary times as video material for the interpretation of English vocabulary.

As for the effect this method can achieve, it is sufficient to show that it is correct to apply multimedia teaching to college English vocabulary teaching. If teachers can use various forms of multimedia flexibly in usual teaching activities, bring students into practical teaching scenario, to inspire students' real experience, so as to achieve the purpose of cultivating students' learning of English and love memorizing words. But, what need to be clarified is that memorizing words is not the ultimate goal of multimedia teaching, the more important is to realize students' flexible use of the words. It is proved through practice that multimedia teaching is the necessary way for students' comprehensive development of English level, and one of the "link" for the good interaction between students and teachers. Whether the multimedia teaching can be applied to the college English vocabulary teaching flexibly and scientifically, will not only affect the students' performance in class and their learning interest, but also will have profound influence on students' learning of English in the future (Liang, 2006).

\section{Conclusion}

To sum up, currently, the application of multimedia teaching in college English vocabulary teaching is still not optimistic, though great achievements have been obtained with the efforts from educational circles. The English teachers at various colleges and universities are still required to pay attention to students' actual needs in actual teaching process, and explore the methods that can help students to improve their learning effect actively, especially shall promote the multimedia teaching to mobilize classroom atmosphere with emphasis, improve students' classroom engagement and optimize classroom teaching effect. While applying multimedia teaching in practice college English vocabulary teaching, pay attention to not focus on "form", that is, on the selection of multimedia teaching content, teaching content should be in the first, as the multimedia teaching is just the extension and 
complement of teaching content. On the other hand, Chinese colleges and universities shall also support the application of multimedia teaching in college English vocabulary teaching from various aspects, especially to increase the investment in education construction, and offer further training to teachers, etc. There is reason to believe that, with the unremitting efforts of the education experts, scholars, and college English teachers, the quality effect of multimedia teaching in the college English vocabulary teaching can be played to the largest extent, to lay a solid foundation for cultivation of national foreign language talents.

\section{References}

Fang, K. M. (2006). Research on College English Vocabulary Teaching. Journal of Beijing Polytechnic College, No. 10, 103-108.

Ji, X. J. (2002). Discussion on Application of Multimedia in Foreign Chinese Teaching. Computer-Assisted Foreign Language Education, No. 5, 210-222.

Li, X. Q. (2008). Analysis of Disadvantages of English Multimedia Teaching and Countermeasures. Journal of Teaching and Management, No. 4, 200-201.

Liang, L. R. (2007). Second Language Acquisition Research and China's Foreign Language Teaching (pp. 177-181). Shanghai: Shanghai Foreign Language Education Press.

Liang, X. (2000). Enlightenment on English Vocabulary Teaching by Cognitive Linguistics. Foreign Languages and Their Teaching, No. 2, 189-190.

Luo, Y. G. (2002). Multimedia Technology and New Mode of Foreign Language Teaching. Computer-Assisted Foreign Language Education, No. 4, 145-157. 